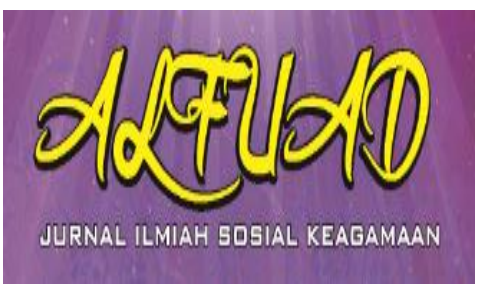

ALFUAD JOURNAL, 5 (1), 2021,(73-85)

(E-ISSN 2714-7606 P-ISSN 2614-4786 )

Available online at

http://ecampus.iainbatusangkar.ac.id/ojs/index.php/alfuad

\title{
Internal Tribal Conflict in The Regency of Tanah Datar in The Reform Era
}

\section{Yanti Mulia Roza}

Institut Agama Islam Negeri batusangkar, indonesia

Email: yanti.mr@iainbatusangkar.ac.id

\begin{abstract}
The purpose of this tribal research is to identify patterns of internal conflict in Tanah Datar District, which is located in three sub-districts. The method used is qualitative descriptive analysis with historical and sociological approaches. The primary sources were interviews with indigenous groups; LKAAM, KAN (Kerapatan Adat Nagari), MTKAAM (High Council for Natural Density Minangkabau), chiefs of the two conflicting parties, chairman of the MUI, Alim Ulama in nagari, secondary sources; books, articles and journals. Data analysis using constant comparative analysis method (grounded theory research). In the reform era, the struggle for the title of sako is not only to get tribal heritage and dignity, but is influenced by political needs and prestige.
\end{abstract}

Keywords: Conflict, Accommodation, Internal, Tribe

\section{INTRODUCTION}

The conflict between custom and religion has been going on for a long time in West Sumatra, culminating in the return of three scholars from Makkah, namely Haji Sumanik, Haji Miskin and Haji Piobang who wanted to purify the teachings of Islam in Minangkabau, especially in Luhak nan Tuo. In 1803 the ulema movement was welcomed by the Tuanku (religious leaders) in Minangkabau, but was challenged by traditional groups. At the same time, the Dutch colonialists used the penghulu (customary leaders) for their political interests, but although the Dutch politically and economically controlled Minangkabau, traditional and religious activities did not change, because customs and religion are inherent in the life of the Minangkabau people.

This conflict and accommodation between traditional and religious groups resulted in a resolution, namely an agreement known as the Basandi Syarak Customary Philosophy, Syarak Basandi Kitabullah (ABS-SBK) which became a binder, unifying the adat and religion in Minangkabau society. However, in actualization there are still conflicts between these two groups. In the postindependence period, conflicts with the government were added. One of the causes of internal conflict in the Minangkabau 
community is regarding the distribution of inheritance, this conflict continues all the time. The inheritance system to the maternal line is difficult to change until now, this was once opposed by the cleric Sheikh Ahmad Khatib Minangkabau during the 20th century Islamic renewal.

The conflict continued until the New Order era. One of the reasons was the enactment of Law Number 5 of 1979 concerning Village Administration, the smallest uniformity of government throughout Indonesia in the form of a Village. According to the people of West Sumatra (West Sumatra) this system has eliminated the concept of nagari (the term for the village in West Sumatra) as it has been used for a long time by the Minangkabau people of West Sumatra. The implementation of the village government system eliminates the cultural values of ulayat (people) land by the certification program. This has also drawn protests from the people of West Sumatra. To accommodate traditional groups, the West Sumatra provincial government formed the LKAAM (Minangkabau Natural Customary Density Institution) Ormas, Bundo Kanduang Ormas in every district and city.

The enactment of the Regional Autonomy Law No. 22 of 1999. In 1999 the beginning of the Reformation, the popular discourses were "Back to Nagari" and "Back to Surau". This discourse has also resulted in conflicting perceptions between indigenous groups and the government and religious groups with the government. Returning to the nagari means that the people of West Sumatra are returning to their efforts to activate the role of local culture in the government system. Indigenous groups wish to maintain and preserve their respective regional customs so that they do not disappear from the lives of the community and the younger generation. This discourse also resulted in horizontal conflicts between traditional institutions in West Sumatra in terms of technical approaches to the community. Religious groups demand the enforcement of Islamic law and eradicate immorality at the provincial to district/city levels, is no exception in Tanah Datar Regency. Therefore, local governments must respond to the wishes of these religious and customary groups.

Conflicts over heirloom titles and heirloom treasures continued at the tribal and Nagari levels in the Reformation Era. The government accommodates indigenous peoples and religions by issuing Regional Regulations, appeals, and appeals to Governors and Regents or Mayors relating to Islamic Shari'a rules and those relating to customs. Conflict between customary, religious and government institutions occur at the 
district level. Happening internal tribal conflicts over the title of inheritance and inheritance. There were fundamental changes as a result of the religious revolution, after the collapse of the New Order, there were regulatory changes during the 15 years of the Reformation.This research focuses on examining the conflict and accommodation among ethnic groups in Tanah Datar Regency, West Sumatra. .

\section{METHOD}

The method used in this research is qualitative descriptive analysis based on concepts and theories that are considered relevant [Sitting Abdurrahman. 1999: 3]. SWhile the description presented will be analyzed from the perspective of a number of phenomena and patterns of conflict and accommodation inter-agencyor group. The form of the research is a case study, taking several cases that occurred at the district level and several cases at the nagari (village) level. approach; historical, sociological. conflict study and accommodation between customs and religion involving two institutionsmajor actors who play a role in implementing the ABS-SBK philosophy. In interactionIn achieving their respective goals, there is often a conflict of perception and accommodation often occurs. Historical approach used to understand the chronological characteristics of the period government and conflict background sustainable in West Sumatra. The sociological approach is used to see the behavior of each community group in social and religious interactions. Sociology is a special science to study social aggregates and groups in institutional organizations, as well as the factors and consequences of changes in social institutions and organizations.Peter Connoly, 2002: 271-172)].

Data collection is done by looking directly at the social facts of the community, namely religious social activities and ritualscustoms carried out by the community, both personally and in groups. Local government documents Tanah Datar district and West Sumatra Province which are used as primary data regarding the topics of this research include: regional regulations, customary and religious agreements, interviews, as well as government documents, customary documents petitihboth written and unwritten (oral) from informants of traditional, religious leaders and former local government officials. While secondary and supporting data were obtained from magazines, local and national newspapers, wise words of adat and religion, as well as contemporary diaries, books in the library of scientific journals, articles and results of field 
observations. All data sources were obtained from in-depth interviews with community leaders, traditional leaders, religious leaders and the results of readings, discussions and studies in the library. Researchers look at rituals in the community in accommodation between customs, religion and government, researcherssee some of the community's ceremonial activities directly. For example, traditional ceremonial customs, religious activities and activities carried out by the Tanah Datar local government. Traditional activities such as ceremonial wedding processions, forty days of babies being born, commemoration of Islamic holidays, batagak gala (inauguration of traditional heirloom titles) and ceremonies other custom [Peter Connoly, 2002: 269].

Among the sources of research subjects in interviews, consisting of: First, indigenous groups; head of LKAAM Tanah Datar, member of KAN (Nagari Customary Density), MTKAAM administrator (Customary Density High Council Minangkabau Nature), /Progenitortribal chiefs from both sides of the conflict, Bundo biological, clever clever. Second, religious leaders; MUI chairman (Indonesian Ulema Council) Tanah Datar Regency, Alim Ulama in the nagari. Interviews with people involved in religious activities both in the mosque and in the surau. Data analysis in this study was carried out using a constant comparative analysis method (grounded theory research). This analysis is carried out on patterns and cases of conflict and accommodation between custom and religion The indicators that are used as comparison materials are related to the field of leadership, regional policies, institutional and traditional life [Atho Mudzhar, 2011].

The data analysis procedure is as follows; data reduction, data presentation, conclusion drawing and data verification. Research This was done in Tanah Datar Regency West Sumatra Province. Tanah Datar District . This research lasted for 1 year starting from December 2016 to March 2017.

\section{RESULT AND DISCUSSION}

\section{Internal Tribal Conflict in Tanah Datar}

Relevant studies include: First, research by Taufik Abdullah, Adat and Islam: An Examination of Conflict in Minangkabau. The research was conducted in 1966. There is an eternal conflict between customs and Islamic law and the concepts that exist in society are ambiguous. It means that the relationship between people is regulated by customary law and the relationship with God is regulated by religious law. The conclusion of this study shows that society is not able to unite two opposing values, this struggle 
occurs continuously between adat and religion in social fragmentation in Minangkabau.

The identity of the Minang people consists of 4 things, namely having a tribe, a sako title (heirloom), inheritance (high central wealth and low inheritance) and the last religion is one religion, namely Islam. If his religion is not Islam, it means he is not Minang. The title of inheritance is a title that is owned by every tribe in Minangkabau. During the Reformation era,there is a struggle for the title of sako, for example in Nagari Pangian there is a struggle for the title of pusako or datuak (the title of heirloom or datuk) with the person with the title of datuk having an inheritance of heirlooms, such as rice fields, fields and lurah or what is called sako and pusako. The title is won by a person who, according to him, also bears his nephew according to the genealogy or family lineage, but is not recognized by nationality by KAN (Kerapatan Adat Nagari) and is only recognized in tribal circles only his people [Interview Darmayeti: 2017].

During the New Order era, the government made a bridge to certify ulayat land which was called the mass certificate program from the BPN (National Land Agency), then ulayat lands in the nagari were certified by the ninik mamak or penghulu. According to Muslim, the government has seriously damaged the customary system in the nagari. The reason is that with this regulation, the penghulu and his nephews can easily sell ulayat land, whereas initially the inheritance was for the benefit of the penghulu.in carrying out the wheels of tribal leadership in order to uphold customs, not personal interests, this happened during the New Order period and continued in the Reformation Order. The Reform Order has even further undermined indigenous peoples and the government is increasingly not synergizing with indigenous groups. [Muslim Interview:2017].

According to the head of Bundo Kanduang nagariSikaladi Pariangan that the heirloom title conflict in the Pariangan nagari is in line with the land dispute conflict. The ambiguity of the division of high inheritance inheritance (high inheritance is a hereditary property inherited from ancestors controlled by tribes) in the previous era so that the conflict passed down to their children and grandchildren (Inayah Interview: 2017). The findings in the field are mostly about the problems of sako (datuak or penghulu title) and pusako (heirloom treasures) that occur in tribes in the nagari in Tanah Datar Regency. This study only took case samples in 3 villages, namely Nagari Pariangan in Pariangan District, Nagari Limakaum in Limakaum District and 
Nagari Batu Bulek in North Lintau Buo District, Tanah Datar Regency.

Sako and pusako conflicts often cannot be resolved by consensus among families and tribes, sometimes conflict cases are forced brought to the district court and even to the Supreme Court. Many dispute complaints cannot be resolved by the court because the court does not dare to enter customary territory, so land disputes like that are returned to customary settlements [Jubaedah Interview: 2017]. Even if it cannot be resolved by custom, eventually the two parties to the dispute are hostile or in conflict all the time.

This conflict continued to occur both in the New Order and the Reformation Order, eventually this problem hung and there were occasional verbal wars between the two disputing parties, such as the case of the seizure of inheritance in the Pariangan village.Pariangan district. Land disputes that occur between two families within the tribe when it cannot be resolved by custom, then the two sides of the family are hostile to each other to their children and grandchildren, even for one generation to two generations there is conflict. Cases like this happen a lot, not infrequently wars of words and revenge smolder to the death of not attending each other's traditional activities. [Interview Inayah: 2017]
The motivation for fighting over the title of adat (datuak) for some community leaders is to gain prestige in the community so that they get the sympathy of the people they lead. There are at least four things that cause a person to have a title and be called a datuk: 1) Due to old age (call his grandson); 2) The factor of mastery of customary knowledge; 3) The title given through the slaughter of buffalo in the nagari; 4) The title that applies in the red land (currently burial) the corpse of the old datuk) [Syahril Amga interview: 2017]. The titles up for grabs are the third category of the title of datuk, the title given through the slaughter of buffalo and the fourth category of titles that are dilewakan (called) in the red land (cemetery). Cases of fighting for the title of datuk often occur, for example in Nagari Pangian Lintau Buo and in Nagari Tigo Jangko, these cases are difficult to resolve, the party with the money will win in this matter. Because the decision is that ninik mamak and ninik mamak can be bribed with money to side with one of those fighting for the title [Muslim Interview: 2017]

Conflict over heirloom titles before the Reformation Orderdifferent from the Reform Order era. The factors for the title of datuk to be contested are first, the motivation to get an inheritance; second, encouragement from the nuclear family 
and the mamak of the saparuik to maintain the existence of their family; third, just want to get prestige/respect in the community so that with the title of datuk will be close to officials both executive and legislative. Presumably the direct election system makes executive and legislative candidates approach the penghulu (tribal head) so that they get vote support through the position of datuk katena datuk is considered a person who has tenure, at least the nephews he leads [Interview:HM. Yunus Sirhan: 2017]. The case of conflict over titles in Nagari Batu Bulek is the same as in other villages, namely sangketa sako (dayuk titles) and pusako (heirlooms). Culture of deliberation Consensus is still ongoing to resolve the nagari or kampuang (kampung) issues, but the conflict over the sako title is not easily resolved by deliberation.

The internal tribal conflicts that occurred were a continuation of past conflicts, during the Reformation period conflicts within the tribes were increasingly prevalent. This is due not only to obtaining inheritance, but rather to the existence of the tribe, the authority to lead the tribe. By bearing the title of datuk or heirloom title, automatically social status will increase in the community and social goals will be achieved. The executive and legislative candidates during the campaign period will approach tribal and religious leaders to mobilize the masses to gain the votes of the people who will vote for them in the legislative or regional head elections (elections for regional heads) and it is not uncommon for these tribal chiefs to participate in the contestation of legislative elections (elections). legislative).

The above display corresponds to Conflict theory perspective Randhal Collins said that conflict did not leave the theory of solidarity, social, social ideals, social sentiments, and feelings. Power, authority or influence is a trait of an interactional process, not a trait of an individual's personality. The most important thing in Collins' theory is that conflict does not analyze ideals and morals as sacred.George Ritzer. Sociology; 1975: 14].

Conflict cases fighting over the title of inheritance in each nagari have different backgrounds. The following are examples of cases of conflict over the title of sako and pusako in Tanah Datar Regency: a) The case of conflict over the title of inheritance that occurred in Nagari Batu Bulek, North Lintau District. Name the first party who is holding the title of heirloom of the Kutianyie (Kutianyir) tribe's top datuk. The title of inheritance that Datuak Mustafa is fighting for [Final Interview: 2016]. After a long time this title has been carried by the first party, the second party now wants to win the title. 
According to the second party, they should be the most entitled to bear the title of heirloom, because according to the history they received from their grandmother, they were closest to the datuk who held the previous title. the title, therefore the title was given to a man who was on the side of a nephew who was some distance away.

The height of this dispute was when Datuk Mustafa died. Parties 1 and 2 are fighting for the title of heirloom, when the first party decides who will bear the title, but the second party does not agree to it and vice versa. Finally, until now the Sako title could not be confirmed by KAN Batu Bulek Nagari Batu Bulek [Interview Usputra Veferi: 2016]. This problem was tried to be solved by ninik mamak (tribal chiefs) who were gathered in KAN (Nagari Customary Density). KAN facilitated both parties to settle the dispute, but neither party wanted to budge, so the heirloom title of Datuk Mustafa has not been applied to any party until now and his datuk's clothes have been hung (the term is fakum) for a while until one day both parties have agreed. agreed. To re-apply this title to the holder, then it must be done by Alek batagak gala (the inauguration party of the title or the term, releasing / inaugurating the Datuak title). To get rid of this title, you need a large amount of funds, for the party you have to slaughter a buffalo, fill an envelope to give it to the tribal leaders and pay off debts to the mosque, each replacing the title of sako (every year).formalize the title of sako must give some money for the nagari mosque) [Afdirijal interview: 2016]. Disputes like this continue to this day between the two sides.

The traditional title of Paduko Kayo from the Piliang tribe, this sako title has been in the lap of the first party and when Datuk Paduko died, at the funeral (at the funeral in Tanah Merah) it was announced to the public that the nephew who would assume the title was Jalisman. Datuk clothes have been directly handed over to his nephew symbolically. When Datuk Paduko died in 2009 his body was brought to his people's gadang house. In the rumah gadang (traditional house) the ninik mamak first discussed who would be appointed as the head of the head/datuk as his successor, then from the results of the deliberation it was decided that Jalisman (near nephew) would replace the deceased, At the funeral it was announced that as the successor or recipient of the Dauak Paduku throne was Jalisman and his datuak's oversized clothes were immediately put on symbolically at that time. The second party wanted to win the title because according to him from Tungganai (another grandmother) he felt entitled to also bear the title of sako. A conflict arose between these two mounts. The second party 
approached the village leaders so that he would be recognized in KAN. This second party built their own gadang house and made their own oversized clothes because in that village he was a famous and rich person. In the end, KAN inaugurated or inaugurated the second party who won the title. The second party wanted to win the title because according to him from Tungganai (another grandmother) he felt entitled to also bear the title of sako. A conflict arose between these two mounts. The second party approached the village leaders so that he would be recognized in KAN. This second party built their own gadang house and made their own oversized clothes because in that village he was a famous and rich person. In the end, KAN inaugurated or inaugurated the second party who won the title. The second party wanted to win the title because according to him from Tungganai (another grandmother) he felt entitled to also bear the title of sako. A conflict arose between these two mounts. The second party approached the village leaders so that he would be recognized in KAN. This second party built their own gadang house and made their own oversized clothes because in that village he was a famous and rich person. In the end, KAN inaugurated or inaugurated the second party who won the title. b) The case that occurred in Nagari Pariangan, Pariangan District, the title being contested was Datuak Marajo from the Koto tribe, this sako title still has the heirloom of satumpuak (a pile) of rice fields for those who hold the sako title Datuak Marajo. Since Datuk Marajo died in 2000, no one has held this sako title because the first and the second parties did not agree with each other. The second party did not agree with the appointment of the heirloom title in the lap of the first party and vice versa the first party did not want to give the title to the second party, because they did not agree within his clan. So the KAN in the Parianagan nagari could not ratify it, so there were no representatives of this tribe who represented the density of the nagari adat. Until now the problem of conflict over the title of Sako Datuak Marajo could not be resolved. Conflicts like this are detrimental to the tribe in the nagari, namely there is no representation in the customary density of the nagari [Interview Datuk Siema: 2017]. The researcher interviewed with the first party that for our side there is no problem, if it is not recognized in KAN and in a state, our father is not included in KAN and nagari meetings because we do not need legitimacy from the ninik mamak (KAN). For the first party, there is no need for formal acknowledgment from KAN or the nagari, the important thing is that the 
nephew's son still recognizes as the leader of his tribe and there are nephews (families) who will be led by his datuk, while the party who seizes is called the second party only leads a few families even though in nagari are recognized by the government and KAN [ Zainal Abidin interview, 2017]. In fact, this second party was elected as the chairman of KAN in the nagari.

The nephew (nephew of a penghulu of a younger or older sister) who recognizes the penghulu to the first party is not allowed to have customary relations with the second party penghulu. It is not allowed to invite a second party to parties, deaths and other traditional celebrations and vice versa if invited by a second party is not allowed to attend. If found violating, the nephew (tribal member) who violates will be subject to sanctions even the heaviest sanctions are removed from the mount or no longer recognized in the mount.

\section{The case that occurred in Nagari Limakaum, Limakaum District}

The case of the struggle for the title of sako and pusako in the Five Peoples of the Patopang Tribe, the first and second parties felt they deserved to hold the title, but KAN could not settle it, so until now the title was just put down, it could not be ignored or inaugurated because there were two conflicting parties, to waive the title was not approved by the ninik mamak nagari (KAN).

Based on the cases that have been put forward and from the data from free interviews from community leaders in the villages in Tanah Datar Regency, the researcher concludes that in almost every village there are cases of conflict over the title of inheritance and inheritance. In the Reformation Era, each tribe member wanted to maintain their identity and because of the growing development of tribal members who had the desire for the goals described above.

People who are well-known for their religious beliefs with the ABS-SBK philosophy, but in terms of the existence of heirloom titles, each group wants to get and maintain it, even though the consequences will be hostile under customary law all the time. This is in accordance with the theory put forward by Jeffrey Hadler that conflicts are the dynamics of the development of Islamic thought and movement in West Sumatra., Minangkabau Muslim culture and cultureencourage agg ressiveness. Minangkabau is a unique area, in the midst of a strong religious culture, besides that, matrilineal (customary) culture can also grow and develop. The richness of the socio-cultural dynamics of Minangkabau makes it one of the ethnic groups that have 
played a role in the process of nationbuilding[Jeffrey Hadler, 2008: 30].The similarity with Taufik Abdullah's research is that there is conflict in Minangkabau society. The difference is in the subject of the conflict, TaufikAbdullah saw eternal conflict between ad at and religion, while in this study we find eternal conflicts within the tribe due to the issue of inheritance and the title of sako (datuk).

Almost every tribe in the villages in Tanah Datar Regency has conflict, although with different backgrounds. From the field findings, the three focal points of the cases investigated are the tendency of the community to want to strengthen tribal unity and at the same time their tribal customs. Because in the Reformation Era for the 2006-2015 period, the local government has strengthened the existence of tribal chiefs for community development, to apply the ABS-SBK philosophy, as can be seen from several regional regulations that accommodate traditional groups, in this case tribal chiefs (penghulu) who are members of the KAN institution.As Nagari Pariangan Jorong Sikaladi has customary rules and sanctions imposed in the Nagari. Some of the customary agreements formulated by the tribal chiefs in Jorong Sikaladi that are valid to date are: No marriage of the same ethnic group. In the Koto tribe, the Koto tribe, namely the Malay Koto and the
Pisang Koto, may marry, as well as the Dalimo tribe (Dalimo long and Dalimo singkek/short), but between umbrella Datuak Marajo and payuang Datuak Siama / Datuak Majo Basa / Datuak Bunsu cannot marry, because these are called se-tribes. You can't mix two women of the same ethnicity. It is not permissible for a woman to marry the husband of another woman of the same ethnicity (even though her first wife has allowed it). Not allowed to marry without the knowledge of niniak mamak (elopement), if there is a violation of customary rules or religious norms (zina), then customary sanctions are applied, in the form of; expelled from the village, for those who marry within the same ethnic group are ostracized from society, for those who elope, pick up their husbands from women who are ethnic groups, commit adultery.

Conflicts can sometimes be resolved by custom and some have to be resolved through civil or criminal law applicable in the Unitary State of the Republic of Indonesia (NKRI) and not infrequently these conflicts cannot be resolved at all. So that in one tribe they do not visit each other in traditional ceremonies carried out or held by both parties. However, in terms of daily interactions, apart from traditional affairs, there is still a harmonious relationship. 


\section{CONCLUSION}

The internal tribal conflicts that occurred before the Reformation were caused by the struggle for the title of sako and inheritance. In the reformation era, it was not solely because they wanted to seize inheritance and sako titles. The struggle for the title of sako, the existence of tribes and their rides, but more because they want to be respected and get social status in society. Some of these disputes are settled within the tribe alone, some have to go to the Nagari Customary Court (KAN) and even have to go to court. Uniquely, even though they have internal conflicts within the tribe, they accommodate each other in religious, economic and government affairs activities.

In order to avoid conflicts within the ethnic groups in Tanah Datar, there must be clear regulations regarding inheritance, sako titles and the election of a datuk that is regulated by a traditional institution (KAN).

\section{REFERENCES}

Abdurrahman, D. (1999). Metode

Penelitian Sejarah. Ciputat: PT. Logos Wacana Ilmu.

Abdullah, T. (1966). Adat and Islam: An Examination of Conflict in Minangkabau, Jurnal Indonesa, 2(3). Connoly, P. (2002). Aneka Pendekatan

Studi Agama.Yogyakarta: Lkis.
Franz, Von Benda-Beckmann, \& Keebet von Benda-Beckmann, (2012) Identity in Dispute: Law, Religion, and Identity in Minangkabau. Asian Ethnicity, 13(4).

Hadler, J. (2008). Sengketa Tiada Putus, Muslim and Matriarchs: Cultural Rasiliens in Indonesia Though Jihad and Colonialism, Cornell University Pres

M.S, Amir. (2007). Masyarakat Adat Minangkabau Terancam Punah. Jakarta: PT Mutiara Sumber Widya,

Mudzhar, A. (2011). Pendekatan Studi Islam Dalam Teori dan Praktek. Yogyakarta: Pustaka Pelajar.

Ritzer, George. (1975). Sociology: A Multiple Paradigm Science Revised Edition. London. Boston. Sydnney, Toronto.

Wawancara Darmayeti (bundo kanduang keturunan datuak) 4 Desember 2017, jam 15.00 WIB di Lintau Buo.

Wawancara Jubaedah Wakil Ketua Pengadilan Agama Batusangkar, 26 Juli 2017 di Batusangkar.

Wawancara Inayah (ketua Bundo Kanduang), $10 \quad$ Mei $2017 \quad$ di Pariangan.

Wawancara Muslim (tokoh masyarakat), 30 Juni 2017, jam 19.00 WIB di Lintau Buo.

Wawancara Inayah (Bundo Kanduang Sikaladi), 10 Mei 2017, jam 13.00 WIB di Pariangan.

Wawancara Syahril Amga Ketua MTKAAM Kabupaten Tanah Datar 2 November 2017 di Batusangkar.

wawancara Muslim (tokoh masyarakat), 30 Juni 2017, jam 19.00 WIB di Lintau Buo.

Wawancara HM.Yunus Sirhan (ketua IKTD Sumatera Utara), wawncara, 27 September 2017 di Pagaruyung.

Wawancara Akhyar tokoh Agama Nagari Batu Bulek 4 September 2016 di Lintau Utara.

Wawancara Usputra Veferi(anggota KAN Batu Bulek), Sabtu, 3 September 
2016 di Jorong Aur duri, Nagari Batu Bulek Kecamatan Lintau Buo Utara

Wawancara Joni Aryuda, Tokoh masyarakat Batu Bulak, 12 Maret 2018.

Wawancara Afdirijal Tokoh masyarakat Nagari Batu Bulek Lintau Utara, 14 September 2016 di Lintau Utara. Wawancara Tokoh Adat Pariangan Datuk Siema di Paringan, 20 Maret 2017.

Wawancara Zainal Abidin, Tokoh masyarakat Lintau Buo, 01 Maret 2017 di Kecamatan Lintau Buo.

Wawancara Datuk Siema di Pariangan, 20 Maret 2017. Terdapat dalam monografi Nagari Pariangan Kabupaten Tanah Datar. 